\title{
The Comedy-Scape in Apartheid South Africa: A Historical Overview
}

\author{
Jennalee Donian \\ https://orcid.org/0000-0001-8403-5099 \\ University of Fort Hare, South Africa \\ donian.jennalee@gmail.com
}

\begin{abstract}
Comedy during the apartheid era was an integral medium for indoctrination and pacification. It was also a key instrument through which the apartheid regime was contested, and, in the later years leading up to democracy, a means of promoting the nation-building and cultural reconciliation rhetoric. This notwithstanding, its history during this period remains poorly researched and documented both in academia, specifically, and more broadly in the entertainment and media industry. This article therefore traces the development and practice of comedy in the country under apartheid rule, paying attention to how shifts in content, delivery across platforms and stylistic choices mirror changes in the country's socio-political landscape. By exploring South African comedy from a historical perspective, this article further highlights the ongoing connectivity of politics and comedy in a way that simultaneously encapsulates issues of space, place and citizenship in evocative ways.
\end{abstract}

Keywords: apartheid; comedy; humour; politics; South Africa

\section{Introduction}

Many scholars have noted comedy's facility to act as a social "thermometer" (Davies 2011, 248) or "cultural barometer" (Gilbert 2004, xvii), reflecting the broader environing social, cultural and political context in which it circulates. Comedy so conceived can thus trace sites of centralised power, processes of marginalisation, the dynamics of social and cultural relationships, and instances of resistance. Subsequently, a historiography of humour in apartheid South African does more than simply trace comedic trends; it simultaneously encapsulates issues of space, place and citizenship in evocative ways. Within this epoch, humour took on three distinct modes based on their overarching drives: these include: 1) humour as an instrument of social control; 2) humour as social protest; and 3) humour as an instrument of social and political transformation. While I am fully aware of the dangers attendant upon such reduction

\section{UNISA $\cong$}




\section{Donian}

and compartmentalisation, and that these comedic junctures are identified with the full realisation that there is some (albeit very little) thematic and stylistic mingling between them, it is precisely because of their very different utilities that they stand, in this article, as three distinctive comedic stages. In order to keep my investigation somewhat reigned in, so as to have the space to fully explore the history of humour in apartheid-era South Africa, this article restricts its focus to the following comedic forms: stand-up, television, film and theatre. ${ }^{1}$ Moreover, the length and focus dedicated to these media differ-not due to any sort of authorial selection bias, but because the popularity of these comedic discourses has fluctuated across different periods. Also, while comedy has existed in the country in some form or another since at least the 1930s, my examination commences in the mid-1960s when the above-mentioned comedic discourses became increasingly popularised and an influential and powerful source of information and commentary in the public imaginary. While no overview of this type can be exhaustive, the material addressed here can shed light on the types and impact of humour in the socio-political calculus of apartheid South Africa.

\section{Humour as an Instrument of Social Control}

Comedy during apartheid was constrained by several draconian state mechanisms that served to delimit dissentient content. For instance, the Publications and Entertainments Act of 1963, and later the Publications Act of 1974, resulted in the censoring and banning of films, television shows, plays, records, books, live performances and art work considered to be obscene, blasphemous, harmful to social relations, or derogatory towards Afrikaners or the State (Hachten and Giffard 1984, 156; McMurtry 1993, 192). The "State of Emergency" in 1985 further allowed the government to mediate and micromanage press coverage on "subversive statements" against the ruling regime, security force actions, the treatment of political detainees, and boycotts and protests (South African History Online 2015). ${ }^{2}$ Apartheid was thus rife with what Bill Keller calls "the censor's paternalism" - a world of "Whited-out newspapers, happy-talk TV, sex-free cinema and laundered literature" (Keller 1993). Amid this repressive autocratic system, humour primarily served as a propaganda machine - for both indoctrination and escapist pacification.

The media industry - in particular television and film as relevant to this articleperformed an explicitly ideological function by personifying the values, mores and viewpoints of the apartheid regime: they contained mainly White actors, the dialogue

1 Humour and comedy are closely related and sometimes even conflated. However, humour refers to anything that is (or may be) perceived as funny, and the social, psychological and semiotic processes by which this "funniness" occurs, whereas comedy denotes formalised texts and performances that are intentionally designed to be humorous in order to provoke laughter (Palmer 1994, 3-7). Humour is thus the broad category under which all methods of "funniness" fall and comedy is a particular instantiation of that category.

2 Opposition against the state also risked banning or even incarceration, as is evidenced by veteran comedian Mel Miller's arrest by the police in 1985-and subsequent beating-by virtue of his politically subversive views at a solo gig at the Carlton Hotel in Johannesburg (TVSA 2020). 


\section{Donian}

was in Afrikaans (and to a lesser degree, English) and they typically depicted the White South African way of life - characterised by an idealised conservative worldview and Calvinist moral norms, completely overlooking the socio-political tumult of the country (Karam 1997, 1-3). Moreover, these media portrayed Afrikaners as wholesome, heroic and heart-warming characters (Botha 2012, 12), whereas Blacks were negatively depicted as incompetent buffoons, uncivilised, inferior, evil or in servile positions (Britz 2017, 17; Karam 1997, 6-7). In addition to content, these media also reproduced the apartheid ideology of separate development by dividing television services and the film industry along racial lines: there were television channels directed specifically at White audiences and channels dedicated to non-Whites, and there existed a "White cinema industry" and a "Black film industry" (Barnett 1999, 278). Moreover, there was a marked unequal access to television in terms of ownership (not many Blacks owned their own television set) and broadcast signal/coverage (the rural areas were poorly served) (Barnett 1999, 278-279). Comedy, at least in its "mainstream" form, thus largely served the interests of the White middle class.

In addition to proclaiming Afrikaner nationalist ideals, comedy also served to entertain, by which I mean "to distract, to divert from reality, to allow a temporary escape that slows down the raising of awareness" (Tcheuyap 2010, 25). This kind of "opiate" comedy meant that a traditionally subversive performance art like stand-up comedy was largely non-existent, with the exception of a handful of White male comedians such as Joe Parker, Al (Alec) Debbo, Mel Green, Eddie Eckstein, Barry Hilton, Casper de Vries and Mel Miller, who would perform their vaudeville-style string of formulaic gags at bars, hotels and festivals. At this time, stand-up had yet to truly emerge as a genre unto itself, but was rather integrated into theatrical plays, musicals, television comedies and variety acts. For instance, Eckstein, Miller and Green all broached comedy through music: Eckstein performed as the frontman for the comedy music group The Bats (1964 to 1981) and starred in the theatrical musical comedy I Love my Wife (1978-1979; 1982). Miller and Green were part of a folk-comedy band called "Mel \& Mel" (and later "Mel, Mel \& Julian" after recruiting guitarist Julian Laxton) in the mid-1960s, which combined folk music with interludes of jokes and funny stories (Mel Miller n.d.).

Following the advent of television in the country in 1976, Miller, along with Eckstein, starred in the first locally produced comedy series Biltong \& Potroast (1976-1981). The show was emblematic of the style of parochial comedy extant at the time. It featured improvisational comedy battles between local (White) South African and (White) British immigrant comedians, which saw host Clackie (Clark) McKay handing out points based on the quality of the comedians' jokes on a series of randomly selected topics. In keeping with the intense regulatory milieu, the series kept to the scripts to the point that when one of the show's cast, Mel Miller, once slipped in an unapproved joke, the South African Broadcasting Corporation (SABC) did not use him for two years (Blignaut 2010). The series was immensely popular and made comics like Miller, Eckstein, Dennis McClean and Cyril Green household names. There was also a plethora of blithe Afrikaans televisual comedic farce during this time, such as Nommer Asseblief 


\section{Donian}

(Number Please 1979), Koöperasiestories (Cooperative Stories 1982-1987), Spies en Plessié-Met Permissie (Spies and Plessié-With Permission 1989) and Orkney Snork Nie (Orkney Doesn't Snore 1989-1992), all of which revolved around heteronormative middle-class Afrikaner life and lacked any overt political character.

Comedy films during the apartheid era espoused a similar non-political stance as their televisual counterparts, especially those associated with Jamie Uys and Leon Schuster. Following the American Candid Camera format, Uys produced Funny People (1976) and Funny People II (1983) - a hidden-camera series that featured practical jokes and pranks on unsuspecting folks. Then, in 1980, he reached international success for his slapstick comedy, The Gods must be Crazy, which, at the time of its release, broke all box office records for foreign films in the United States (Gugler 2004, 78). Set in the Kalahari Desert in southern Africa, a Coca-Cola bottle drops down from an aeroplane and lands in a Khoisan community (an indigenous African tribe) where the astonished villagers attempt to put it to use, thereby eliciting several hilarious efforts that do not correspond with its intended usage. The tribe begins to fight over ownership of the foreign object, finally considering it to be a curse, and to restore peace, decide to have it thrown over the end of the earth. The tribal leader, $\mathrm{Xi}$, sets out on this journey, encountering modern civilisation and its stranger aspects along the way, including a clumsy scientist and a newly hired school teacher and her class who are taken hostage by a band of guerrilla terrorists. The documentary-style format and the realistic presentation rendered this imagery authentic, thus inculcating a positive view of South African life that bore no resemblance to reality. Uys thus came under criticism for his unrealistic depiction of the homelands and silence on apartheid, which seemingly appeared like a tacit endorsement (Canby 1984). Nonetheless, the popular success of the film led to a sequel in 1989_-The Gods must be Crazy II.

The tradition of slapstick and candid-camera style comedy continued with Schuster and his highly successful (predominantly Afrikaans) films such as You Must Be Joking! (1986), You Must Be Joking! Too (1987) and Oh Schucks ... It's Schuster! (1989). Their comedic formula revolved around a series of farcical short skits and set-up situations where Schuster - in several disguises, many of which featured blackface — pranked the public, concluding with his reveal and his well-known tagline "You've been schuks'd!" Despite the seemingly innocuous nature of much of Uys's and Schuster's comedy, their films were nevertheless imbued with the spirit of apartheid: they naturalised White superiority by representing Whites as heroes paternally governing the Blacks, who are negatively represented as subordinate, reprobate and "Other"-and thus unable to function in a modern society or govern themselves, making them the centre of comedic ridicule (Mamatu 2006, 78; Norton 2015, 8). In this way, these films also legitimated a perspective of White elitism and buttressed the apartheid notion of separate development, portraying homeland life (rather than urbanisation) as more apt for Black communities. 


\section{Donian}

A number of lesser-known comedy films were also produced for Black audiences, but for paternalistic reasons. The state introduced the B-Scheme film subsidy programme in 1972 in an effort to mollify the Black masses through "wholesome" soporific entertainment at a time when resistance movements were ramping up protest against the apartheid regime. ${ }^{34}$ That is, the "Black film industry" was seen as a medium through which the government could actively control the ideological content of films aimed at Blacks during the tumultuous 1970s and 1980s. Key to this was avoiding political, economic and social issues (Angus 2020), which also aligns with the ostensibly facetious agenda of "White cinema." At the level of cinematic style and aesthetic, as well as distribution and exhibition, however, Black films differed drastically from their White counterparts. First, they were produced in an indigenous African language and consisted of a primarily Black cast. Second, they were produced by White (mostly inexperienced) filmmakers who sought to take advantage of the financial incentives offered by the film policy; thus, artistic merit was not a priority and film quality suffered from poor lighting, sound and editing, minimal costumes and recycled scenes (Angus 2020; Paleker 2009, 1). In fact, the films were often simply a hodgepodge of bits of footage slapped together in the most rudimentary fashion. Relatedly, they did not reflect the political and social needs or desires of Black audiences (Paleker 2009, 1-2). Furthermore, the films were only screened at schools, churches and community halls in the rural areas rather than at designated cinemas (SAHO n.d.).

The comedy films produced through this scheme largely followed the slapstick tradition (like that of White comedy films), such as Inyakanyaka (Trouble) (1977) and Upondo no Nkinsela (Upondo and Nkinsela) (1980)_both produced in the Zulu vernacularwhich revolved around two friends who find themselves in hilarious situations. The (now) iconic Ndaba Mhlongo starred in both films, although his portrayal of the Mshefane character in Inyakanyaka is undoubtedly his most revered role, with many noting that his extravagant (almost theatrical) exaggerations and overly dramatised characterisations - replete with quirks, idiosyncrasies and astute attention to comic timing — paved the way for this stylised form of acting in Black South African comedy and film (Actor Spaces 2019). Another notable mention is Ngaka (Doctor) (1977)_also produced in Zulu-about the clash between Western and tribal medicine. This traditional-modern and rural/urban dichotomy harkens back to Jamie Uys's The Gods Must Be Crazy, and once again speaks to the way in which film assumed a surrogate role for the apartheid government by (explicitly or implicitly) presenting Africans as "different" to Whites. Significantly, even though Inyakanyaka and Ngaka were directed by Simon Sabela (one of the few Black filmmakers at the time), it is important to

3 This policy was dubbed the B-Scheme subsidy programme to distinguish it from the general (and much larger) A-Scheme subsidy established for Whites earlier in 1956.

4 Here, I refer to the Black Consciousness Movement (BCM) - a grassroots anti-apartheid student movement led by Steve Biko that emerged in the country in the 1970s. The movement instigated a social, cultural, and political awakening in the country's Black population, uniting Black students, professionals and intellectuals in the shared aim of liberation. The BCM reached its zenith in the Soweto Student Uprising of 1976 (mentioned below). 


\section{Donian}

remember that this was under the patronage of White-owned production companies such as Heyns Films. As such, the opportunity for African self-expression or selfrepresentation was severely curtailed. Nevertheless, the mere presence of Blacks behind the scenes (operating as film technicians, production assistants, etc.), onscreen and the inclusion of African native tongues, have to be read as at least sub-textually subversive - even in the most saccharine of films.

\section{Humour as Social Protest}

Despite censorship and the increasing nationalisation of the media industry, political comedy was possible; however, it was mainly limited to the theatre. The emergence of a "theatre of resistance" was inextricably linked to growing civic unrest (as intimated above) that had been developing over the preceding decade and a half, culminating in the Soweto Student Uprising of June 16, 1976, where several thousand African students took to the streets of Soweto to protest the introduction of Afrikaans as the medium of instruction in local schools, and were met with fierce police brutality. The event crystalised generations of Black discontent, sparked international media attention and wrought an irrevocable shift in the consciousness of all South Africans, triggering a countrywide revolt against the apartheid government. The theatre responded to such radical developments chiefly through satire, and particularly under the names of Robert Kirby and Pieter-Dirk Uys (no relation to Jamie Uys). For instance, Kirby wrote and performed in a number of satirical revues that exposed the patronising façade of White liberalism and the inherent racism of the franchise. These revues consisted of anecdotes, songs and parodies, and followed the Juvenalian tradition: they were dark, tragic and serious, more than comedic, and their prevailing tone was one of inflated scorn, aggression and scepticism (Tennant 1999). Furthermore, Kirby made use of direct satire, meaning his plays were filled with personal invectives aimed at clearly identified personages or institutions across his socio-political landscape - rather than criticisms conveyed through hints or allusions (Hile 2017, 12). Such persons and institutions included heads of state, the National Party, the censorship board, the SABC, the women's liberation movement, local television personalities, academics, reform policies and even fellow satirists (among them, Pieter-Dirk Uys). Some of his plays include The Receiver of Revenue Show (1973), The Dot Dash Show (1975), How Now, Sacred Cow? (1977), Quodlibet (1978), Separate Development (1980), It's a Boy! (1982), Brave New Pretoria (1984) and Panics (1991). Among the most prominent of these plays was It's a Boy! - that reflects the bigotry of White lower-middle-class South Africa, which was controversial for a number of reasons: first, it demonstrated the absurdities of apartheid by deliberately employing a multiracial cast. Second, it utilised derogatory terms like "kaffir" and "nigger" and racial jokes like the one about the leader of the Ciskei, Chief Lennox Sebe, where Theunis Nel (played by Neil McCarthy) says: "Chief Sebe goes into a filling station. He says to the boy, fill her up and pump my lips to two comma three" (Kirby 1982). The latter resulted in the Publications Appeal Board ordering various deletions on the basis that the pejorative language and racial insults were harmful to Black and White relations; however, the case was passed owing to the 


\section{Donian}

argument that these literary devices were used humorously and critically in the context of a play (and not in everyday life) to expose racial bias (McMurtry 1993, 199). The said board further demanded cutting the scene that featured the onstage kiss between a White woman (the character of Juliana Knoesen) and a Black man (the character of Pepsi). Resultantly, Kirby rewrote the scene, but in a manner that satirised the censors by having Theunis, a terrible bigot, kiss the Black character: When Juliana was about to kiss her boyfriend, Pepsi, her father (Jiggs) stepped in and said, "No, the Immorality Act does not allow you to kiss a Black man" (Kirby 1982). However, the Act is not specific about matters regarding the kissing of Black men and White men, thus Jiggs said, "Theunis, you kiss Pepsi for her" (Kirby 1982). This scene is emblematic of the way in which Kirby would reference the censors in his plays in order to patronise them and expose the ridiculousness of their directives.

While Kirby's works were notoriously contemptuous and laden with mordant humour, Uys's political humour was more oblique and "playful" in order to circulate. Indeed, Uys's comedy mimicked the Horatian tradition: he approached his targets of ridicule with amused and tolerant contempt in the form of affectionate parodies and gentle caricatures (Nilsen and Nilsen 2019, 165). In particular, he created a female alter ego in drag, Tannie (aunty) Evita Bezuidenhout, whom he introduced to the nation in his oneman cabaret Adapt or Dye (1981-1982), and who subsequently appeared in Farce About Uys (1983), Total Onslaught (1984) and Beyond the Rubicon (1986). Evita was characterised by her big coiffed black wig with white highlights (symbolic of race relations in the country), bright red lipstick, extravagant jewellery and her garish outfits, which were often augmented with Nationalist Party insignia (such as a blue, orange and white sash emblematic of the South African flag at the time). Furthermore, "she" was representative of the venerated volksmoeder (Mother of the Nation) figure: "she" was a White Afrikaner patrician and pious housewife (of a National Party Member), patriotic, lovable and stern. Through this character, Uys assumed an ironic mask of an ignorantly idiotic, crass, racist and privileged rightest supporter that allowed him to bypass the censors and made him invulnerable to political correctness and social backlash, while simultaneously arousing audiences' consciousness of the insidious and hypocritical mores of apartheid. For instance, Evita would consistently invoke the names of banned anti-apartheid activists or use racial slurs like the term "kaffir" or "bobbejane" (meaning baboons, in reference to the Black population) or expletives-which were mostly articulated in the Afrikaans vernacular (Uys 1982; 1983). Additionally, "she" would push the boundaries of sex/uality by way of direct sexual allusions, sexual innuendos, her somewhat cheaply provocative outfits ("she" often appeared in leopard print skin dresses which connoted a "tarty" and flashy image antithetical to the image of refined Afrikaans women at the time, as did the subtler exposing of "her" knees when sitting

5 It would be safe to assume that Uys's use of blasphemous and obscene language, expressed in Afrikaans, served to besmirch — or at least compromise - the image of Afrikaner nationalist as righteous Christians. 


\section{Donian}

down in these dresses), or in terms of her son, De Kock, who was depicted as an effeminate homosexual (Uys 1982; 1983).

Most of these activities were either heavily frowned upon within the conservative context of apartheid, or illegal at the time, such as invoking the names of barred individuals, referencing homosexuality or the act of public transvestitism itself. Such comic freedom, as intimated, is inextricably linked to the idealised volksmoeder image, as any attack on Evita would have been an assault on Afrikaner womanhood; also, prosecution against a comic persona (especially a drag queen) would have made the apartheid government look absurd (Senelick 2000, 475). In addition to offering satirical commentary during the apartheid-era, Evita also played a participatory role in the interregnum to democracy by becoming a public face for White change and adaptation and thus presenting a hopeful vision of the future. Indeed, Uys's cabarets produced between 1990 and 1994 (and shortly thereafter) were primarily directed at White audiences, whereby Evita aimed to help "her" audiences cope with the loss of privilege, confront their fears about a multi-racial South Africa and their inherent racism, as well as to humanise those who had been labelled the "enemy" by the apartheid government (Sizemore-Barber 2016, 199). Evita has since gone on to become a national celebrity, having appeared regularly in plays, on television and in films, and has even been accorded similar status to such illustrious and influential personages as Nelson Mandela, F. W. de Klerk and Bishop Desmond Tutu.

Protest theatre was by no means the exclusive domain of Whites; in fact, it was quite the contrary. Non-Whites were increasingly using the theatre as an effective forum to voice their grievances with the reigning dehumanising political system. Like their White counterparts, the plays served to expose the atrocities of apartheid, but, in addition, they also attempted to restore dignity to (African and Coloured) traditional life and culture, to reinforce unity and identity, and to heal and empower (Panday 2004, 10). Most successful among "Black protest plays" was undoubtedly Percy Mtwa, Mbongeni Ngema and Barney Simon's Woza Albert (Rise Albert) (1981). An amalgam of oral history and political protest articulated through slapstick, singing, physical comedy and satire, the play ridiculed the supposedly "Christian" principles of the apartheid regime by speculating on what would happen if Jesus chose the country at that time for his "second coming." Relatedly, it tackled issues such as the exploitation of Black South Africans in the workplace, the economic world and education, as well as misplaced families and police brutality. It did so in the tradition of Grotowskian "poor theatre" (Grotowski 1969): it used minimal props, costume, make-up and cast (there were only two actors-Mtwa and Ngema), and relied heavily on body transformation and mimicry as a means of expression. That is, the play displayed a far greater commitment to political commentary than to aesthetic considerations, believing that theatre at the time had a moral obligation to join the fight against the oppressive regime and help to conscientise and mobilise the people. This type of dynamic and physical theatre also undoubtedly served to capture the countenance of poverty and oppression among the Black population. The play was unique for its time, in many respects, most notably by 


\section{Donian}

countering the tradition of racial caricature institutionalised in colonial South African culture by comically depicting Whites as barbaric savages. Relatedly, and unlike other prevailing media representations, it offered a realistic portrayal of the Black experience under apartheid rule, marked by suffering, oppression and injustice. It also provided an opportunity to bring African orality and ritualistic performances into traditional theatre practice in terms of Zulu song and dance. The production became an international sensation and played a major role in raising global support for the anti-apartheid struggle through its world tour (Jenkins 1998, 423-424).

Another important example of protest theatre in South Africa was David Kramer and Taliep Petersen's District Six (1987-1989): a musical revolving around an inter-racial love triangle amidst the plight of Cape Town's District Six residents (predominantly Coloured people) who were forcibly removed from the area in the 1960s following its designation as a Whites-only zone. Employing satire and invective, it highlighted the brutality and inhumanity of apartheid, captured both the language and sentiment of a forgotten people and became a significant trailblazer in the cultural rediscovery of this community (Siebörger 2016) - even inspiring the idea of a "permanent memorial" to the canton, which was actualised in 1994 with the establishment of the District Six Museum in Cape Town (Willoughby 2002). This highly acclaimed musical broke all theatrical box-office records in 1986 and played over 447 performances throughout South Africa and abroad to audiences totalling around 289500 people (McCormick 2002, 205). More importantly, the production breached a number of apartheid laws, not least of which was featuring inter-racial relationships and visually recognisable queer identities in public discourse (Munro 2012, 109). Its political thrust also extended beyond such thematics by way of Kramer (White) and Petersen's (Coloured) collaboration which, in the context of apartheid, transgressed racial boundaries and cultural practices, pointing to the inanity of segregation. Additionally, despite the fact that most theatre-goers at the time were White, District Six attracted a ground-breaking multiracial audience (Munro 2012, 109).

Although comedy in its theatrical guise seemingly operated as a weapon of protest in the 1980s, it could also be argued that it served to sustain the status quo. For instance, the theatre had limited reach and accessibility, and thus likely functioned as a "safety valve" to insulate critique and political grievances. This would explain why District Six enjoyed national and international success on stage, while several songs from the soundtrack were banned by the SABC (Van der Merwe 2017, 118). Simultaneously, it would appear that political stage productions like the one above, as well as Woza Albert, were co-opted by the state and turned into artistic commodities, as evidence before world opinion that conditions in South Africa were not truly repressive - even when it is obvious that such theatres played specifically to White audiences and not in townships where they could engender dissent. Ian Steadman comments on such "cultural appropriation," noting that it was increasingly even more effective than the state's formal structures: 


\section{Donian}

Hegemonic control in South Africa extends to a view of theatre-outside the townships - as a middle-class enclave where potentially disruptive plays can become cultural commodities in the same way that militant poetry is turned by publication into literary commodities. For the South African government, the valuable by-product of such a process is the impression that the State in South Africa allows a considerable amount of "free expression" and "cultural criticism"-an impression which, in the context of a proclaimed reformist climate, has obvious benefits. (Steadman 1985, 26)

Such radical rhetoric, then, might not have necessarily offered insurgence, but only its illusion. Thus, what is clear, is that comedy up until this time was broadly embedded in the very mechanics of social power, serving as its accomplice.

\section{Humour as an Instrument of Social and Political Transformation}

Protest theatre flourished up until 1990 when ongoing civil unrest, weakening White commitment and international condemnation, led then-President F.W. de Klerk to begin official negotiations to end apartheid. As the country moved towards democracy, humour showed significant potential to serve as a palliative for increased tension and anxiety surrounding political, racial, ethnic and class transformation. It was also a key medium through which nation-building and cultural reconciliation were promoted, especially in its televisual and cinematic guise (Botha 2012, 15; Teer-Tomaselli 2001, 117). These media served as repositories for this rhetoric through multiracial casting and multilingualism, thus also operating, to a certain extent, as a critical public pedagogical tool for cultural and racial tolerance.

A case in point is the sitcom Going Up I, which was first broadcast in 1991 and explored the "new" cultural life in South Africa thematised through Black and White relationships among colleagues at a law firm in downtown Johannesburg, who also frequented the "shebeen" (tavern) located at the top of the firm's building. A combination of comic realism, the allegoric mode and African folktale tradition (Roome 1998, 116), the show combined elements of the "old" and "new" South Africa, as most readily represented by the characters. For instance, Jabulani Cebekulu was a Black colonial-style helper; Mr Reginald Cluver was an old-fashioned White lawyer at the firm; Squeeza was the Black owner of the "shebeen"; Edward Tsaba was the Black associate at the firm; and Klein Piet Gouws was the White Afrikaans-speaking security guard in the foyer of the building. Jabulani, Mr Cluver and Squeeza all signified the labour force under the apartheid system, whereby Blacks occupied menial jobs in service of Whites, "skilled" jobs were reserved for Whites, and taverns were mainly owned by Black females. Edward and Klein Piet Gouws, on the other hand, spoke to the shifts taking place in the industry as the country neared democracy: Edward represented the emerging new Black elite who were increasingly gaining access to semiskilled and skilled occupations, and Klein Piet Gouws signified the abolishment of formal job reservations for Whites as evidenced by his position as a security guard. The sitcom can thus be regarded as a microcosm of the rearrangement of social, racial and economic consigned hierarchies in the "new" South Africa. The success of the series 


\section{Donian}

led to follow-up instalments, Going Up II and Going Up III, which aired from 19982002, and continued to deal with issues facing the country at the time, such as conflicts between African traditionalism and modernism, affirmative action policies and even controversial topics such as pornography and homosexuality (Roome 2002, 49).

Another notable sitcom in this regard was Suburban Bliss (1995). Although the series does not fall within the timeframe periodised in this section, it nevertheless represents the continuation of the nation-building rhetoric and thus deserves a brief mention. The show centred around a Black family, the Molois, and a White family, the Dwyers, living next door to one another and in business together. Through these characters it explored the cultural experiences of both Blacks and Whites heralded by the 1994 elections, communicating both the Afrikaner and African psyche. Among the matters explored was the upward mobility of the Black population as depicted by the Molois, who ran a successful business and owned a modern home in a posh suburb replete with expensive furniture and fashionable Western clothing. To this end, it also alluded to equality in the workplace, which spoke to broader labour transformations taking place in the country such as progressive labour legislation and key programmes aimed at representing a more racially diverse workforce. Additionally, Suburban Bliss also examined the continued currency of racist tendencies among the older generation of South Africans as represented by Ma Moloi who adopted an aggressive stance towards Hempies, as well as Hempies whose conservative Afrikaans background was manifested in his impudent racism and fervent reaction to any possible integration between the two families.

Turning to film, mention must once again be made of Schuster's comedies, which have always existed at the intersections of multiple comic trajectories in South Africa's history, and are truly representative of comedy's evolution alongside rapidly shifting socio-political exigencies. While his films produced in the 1990 s_-Sweet ' $n$ Short (1991) and There's a Zulu on my Stoep (There's a Zulu on my Veranda) (1993) — might not be overt in their nation-building project, they nevertheless responded to this rhetoric by mirroring the "new" South African demographic: they were increasingly produced in English, intended for a racially and culturally diverse audience, and included Black actors as part of the main cast. Like his previous films, the above combined farce, satire and slapstick to bring about humour. However, unlike his prior works, they portrayed a concurrency of multi-cultural perspectives whereby the humour was contingent on misunderstandings brought about by cultural differences such as race, ethnicity and gender. Such diversity and pluralism were most notably explored through inter-racial relationships; such being the case with Sweet Coetzee and Alfred Short in Sweet ' $n$ Short and Rhino Labuschagne and Zulu Mashebela in There's a Zulu on my Stoep. These films also marked a deviation from Schuster's earlier works in terms of racial 


\section{Donian}

stereotyping - at least to some extent. ${ }^{6}$ For instance, in the end scene of the latter film, it is the Black Zulu who finally rescues the kidnapped children from the head of a fascist organisation, the White "Diehard." In this case, the Black character is heroicised while the White character is villainised. Schuster has since continued to reflect the many facets of the South African situation through his films - of which there have been many more-making him the country's most commercially successful comedy filmmaker.

\section{Conclusion}

The South African comedy-scape is too diverse to identify, much less sojourn at, all possible trends, or to do so for equally long. As such, many important individuals, works and comedic forms have been omitted from this article. Furthermore, certain enquiries have had to be overlooked, such as the intersection of gender and comedy, or the extent to which mediatised comedic forms captured, or failed to capture, popular and subaltern humour. Nevertheless, by focusing on comedy in its stand-up, theatrical, televisual and cinematic guise, this study has been able to extrapolate broad trends in the history of mediatised humour in apartheid South Africa. On the one hand, humour seemingly operated as a form of political propaganda, especially in its televisual and cinematic form, intended to persuade national (and international) audiences of the merits of racial segregation and construct a White (particularly Afrikaans) identity within the national paradigm. On the other hand, humour in its theatrical mode was understood as a form of resistance where it served to convince people of the regime's oppressive and violent nature. While humour during the apartheid era clearly both propagandised and challenged the social order, it also played an important role in nation-building and cultural reconciliation as the country transitioned to democratic rule between 1990 and 1994. It did so by creating a cultural space through which to process and address the dramatically reorganised polity and society. Although these three comedic trends noticeably differ in terms of form, content and approach, what is evident from the above overview, is that they are all indicative of stability at a broader level whereby humour functioned in the service of existing power relations, emulating state imperatives. Regardless of whether comedy purports to be solely light and wholly apolitical, or whether it declares its transgressive intentions, it is clear that humour is an indubitable index to South Africa's shifting values and sense of identity and belonging.

With this in mind, future studies might explore humour in the post-apartheid milieu as a means to engage with, and reflect on, issues of power, representation and politics in the democratic dispensation. Relatedly, such scholarly investigations could pay special attention to the quality of, and limits to, democracy in terms of censorship; that is, despite a move away from the obvious censure legislatures of the past, there exist other

6 While Schuster's films during this era often coupled racist and sexist jokes with offensive stereotype in an effort to invert them, the paradox is that such upending of race and gender issues does not overcome the way difference is articulated. That is, the films still portray Blacks and Whites as inherently dissimilar and thus perpetuate unequal relations, as the jokes are predicated on the continued existence of racism. 


\section{Donian}

more implicit mechanisms of censorship at work in contemporary South African humour.

\section{References}

Actor Spaces. 2019. "Ndaba Mhlongo: The Legacy.” September 29. Accessed August 1, 2021. http://www.actorspaces.co.za/index.php/2019/09/29/ndaba-mhlongo-the-legacy-actorspaces/.

Angus, B. 2020. "A Little Known Era of South African Film: The B-Scheme Industry and the Retro Afrika Bioscope Series.” Memory@UCT blog, July 16. Accessed July 5, 2021. http://blogs.uct.ac.za/memory/2020/07/a-little-known-era-of-south-african-film-the-bscheme-industry-and-the-retro-afrika-bioscope-series/.

Barnett, C. 1999. "Broadcasting the Rainbow Nation: Media, Democracy, and Nation-Building in South Africa." Antipode 31 (3): 274-303. https://doi.org/10.1111/1467-8330.00104.

Blignaut, C. 2010. "Laughing Stock.” The Sunday Times, December 12. Accessed October 9, 2020. https://www.timeslive.co.za/sunday-times/lifestyle/2010-12-12-laughing-stock/.

Botha, M. 2012. South African Cinema 1896-2012. Chicago: University of Chicago Press.

Britz, D. 2017. “Bosbok Ses Films: Exploring Postheroic Narratives.” Master's dissertation. University of Pretoria.

Canby, V. 1984. "Film View; Is 'The Gods Must Be Crazy' Only a Comedy?” The New York Times, October 28. Accessed November 5, 2020 https://www.nytimes.com/1984/10/28/arts/film-view-is-the-gods-must-be-crazy-only-acomedy.html.

Davies, C. 2011. Jokes and Targets. Indianapolis: Indiana University Press.

Gilbert, J. 2004. Performing Marginality: Humor, Gender and Cultural Critique. Detroit: Wayne State University Press.

Grotowski, J. 1969. Towards a Poor Theatre. London: Methuen.

Gugler, J. 2004. "Fiction, Fact, and the Critic's Responsibility: Camp de Thiaroye, Yaaba, and The Gods Must Be Crazy.” In Focus on African Films, edited by F. Pfaff, 69-88. Indianapolis: Indiana University Press.

Hachten, W. A., and C. A. Giffard. 1984. The Press and Apartheid: Repression and Propaganda in South Africa. Madison: University of Wisconsin Press. https://doi.org/10.1007/978-1-349-07685-7.

Hile, R. E. 2017. Spenserian Satire: A Tradition of Indirection. Manchester: Manchester University Press. https://doi.org/10.7228/manchester/9780719088087.001.0001. 


\section{Donian}

Jenkins, R. 1998. "South African Political Clowning: Laughter and Resistance to Apartheid." In Fools and Jesters in Literature, Art, and History: A Bio-bibliographical Sourcebook, edited by V. K. Janik, 419-427. Westport, CT: Greenwood.

Karam, B. 1997. "Putting a Future into Film: Cultural Policy Studies, the Arts and Culture Task Group and Film Reference Group (1980-1997)." Master's dissertation. University of Natal.

Keller, B. 1993. "The World: The Surge to Suppress Persists in South Africa." The New York Times, August 1. Accessed July 12, 2020. https://www.nytimes.com/1993/08/01/weekinreview/the-world-the-urge-to-suppresspersists-in-south-africa.html.

Kirby, R. 1982. It's a Boy! Johannesburg: Triad.

Mamatu, T. 2006. “The Colonising Laughter in Mr Bones and Sweet and Short.” Master's dissertation. Wits University.

McCormick, K. 2002. Language in Cape Town's District Six. Oxford: Oxford University Press.

McMurtry, M. E. 1993. “The Playwright-Performer as Scourge and Benefactor: An Examination of Political Satire and Lampoon in South African Theatre, with particular Reference to Pieter-Dirk Uys. PhD thesis. University of Natal.

Mel Miller. n.d. “About Mel Miller.” Accessed June 14, 2020.

https://www.melmillercomedian.co.za/mel-miller-about.html.

Munro, B. M. 2012. South Africa and the Dream of Love to Come: Queer Sexuality and the Struggle for Freedom. Minneapolis: University of Minnesota Press.

Nilsen, D. L. F., and A. P. Nilsen. 2019. The Language of Humour: An Introduction. United Kingdom: Cambridge University Press.

Norton, S. D. 2015. "Primitivism and Contemporary Popular Memory." PhD thesis. University of Oregon.

Paleker, G. 2009. “Creating a 'Black Film Industry': State Intervention and Films for African Audiences in South Africa, 1956-1990.” PhD thesis. University of Cape Town.

Palmer, J. 1994. Taking Humour Seriously. London: Routledge.

Panday, S. 2004. "Singing for the Fatherland: Four South African Protest Plays." Master's dissertation. University of KwaZulu-Natal.

Roome, D. 1998. “Humour as 'Cultural Reconciliation' in South African Situation Comedy: An Ethnographic Study of Multicultural Female Viewers.” PhD thesis. University of Natal. 


\section{Donian}

Roome, D. 2002. “The Serious 'Consequences' of Comedy: Negotiating Cultural Change and Difference Through Humour.” South African Theatre Journal 16 (1): 44-62. https://doi.org/10.1080/10137548.2002.9687741.

SAHO. n.d. "A History of the South African Film Industry timeline 1895-2003." Accessed August 1, 2021. https://sahistory.org.za/article/history-south-african-film-industrytimeline-1895-2003.

Senelick, L. 2000. The Changing Room: Sex, Drag and Theatre. Routledge: Taylor and Francis.

Siebörger, R. 2016. “A Musical as Pubic History: 'District Six'.” Public History Weekly, June 16. Accessed July 5, 2021. https://public-history-weekly.degruyter.com/4-2016-22/musicpublic-history/. https://doi.org/10.1515/phw-2016-6332.

Sizemore-Barber, A. 2016. "A Queer Transition: Whiteness in the Prismatic, Post-Apartheid Drag Performances of Pieter-Dirk Uys and Stephen Cohen." Theatre Journal 68 (2): 191211. https://doi.org/10.1353/tj.2016.0040.

South African History Online. 2015. "State of Emergency-1985," July 21. Accessed October 9, 2020. https://www.sahistory.org.za/article/state-emergency-1985.

Steadman, I. 1985. “The Other Face.” Index on Censorship 14 (1): 26-27. https://doi.org/10.1080/03064228508533834.

Tcheuyap, A. 2010. "Comedy of Power, Power of Comedy: Strategic Transformations in African Cinemas.” Journal of African Cultural Studies 22 (1): 25-40. https://doi.org/10.1080/13696810903488561.

Teer-Tomaselli, R. 2001. "Nation Building, Social Identity and Television in a Changing Media Landscape." In Culture in the New South Africa: After Apartheid, Vol. 2, edited by R. Kriger and A. Zegeye, 117-137. Cape Town: Kwela Books.

Tennant, P. M. W. 1999. "Mask or Mirror? A Study of Juvenal's Satires as a Reflection of Authorial Personality and Perspective." PhD thesis. University of Natal.

TVSA. 2020. "Mel Miller.” Accessed October 9, 2020.

https://www.tvsa.co.za/actors/viewactor.aspx?actorid=9222.

Uys, P. 1982. Adapt or Dye. [video]. Johannesburg: Ster-Kinekor.

Uys, P. 1983. Farce About Uys. Johannesburg: Jonathan Ball and Ad. Donker.

Van der Merwe, S. 2017. On Record-Popular Afrikaans Music and Society, 1900-2017. Stellenbosch: Sun Press. https://doi.org/10.18820/9781928357124.

Willoughby, G. 2002. "Music, Memory, Myth”. Mail and Guardian, October 25. Accessed July 17, 2020. https://mg.co.za/article/2002-10-25-music-memory-myth. 